\title{
第11回日本脳卒中学会講演抄録
}

期日 昭和 61 年 4 月 7 日 (月), 8 日（火）

会場 福岡市民会館

会長 九川大学医字部脑神経病研究施設外科 北村 勝俊

\section{<会長講演 $>$}

\section{破裂脳動脈瘤の手術時期 \\ 一国際共同研究に和ける日本脳神経外科医の成績一}

\author{
北村 勝俊 \\ 九川大字医字部脳神経病研究施設外种
}

I.はしめに

頭蓋内動脈瘤の破裂は，いわゆる特発性くも膜下出 血の原因として最も重要なものてある。初回破裂は， ほとんとの場合, 他の臓器には異常のない, 一見健康 な者に突発し，幸いに初回破裂による死を免かれた場 合も，再破裂の危険か大きく，累計死亡率は，初回破 裂 1 週て $40 \% ， 3$ 週て $67 \% ， 6$ 週て $81 \%$ といわれてい る ${ }^{5}$. 再破裂防止のためには, 外科的に動脈瘤頸部をク リフフ又は結禁により閉塞するのか根佁的とされ，そ の手技は，近年のマイクロサーセリ一の普及により， ほ涪確立されたものといえる。しかしなからその手術 時期については, 古くから議論され続けて㧍り, 未た に定说といらへきものかな、発作後急性期の, 不安 定な時期ての手術に比へて晚期の安定した時期の方か 安全て死亡率も低いことはすへての脳外种医の認める ところてあるか, 待機中に再破裂により死亡する危険 か，ことに破裂後 1 週間て非常に大きいことも又知ら れ過きている汪との事実てある。とのような状態の患 者に，何時手術をするのか最もよい結果を招くことに なるのか，この問題についての解答を求めて,「破裂脳 動脈瘤の手術時期について」の国際共同研究か, 1981 年 1 月より1984年 6 月にわたる間行われた。この共同 研究には, 世界の 68 ノターか参加し, 総症例数 3,521 , らち手術例数 $2,922(83 \%)$ か集計分析された。 わか国 からは，脳動脈瘤の外科関心之経験の探い12名の研
表 1 研究分担者と施設

\begin{tabular}{rl|l}
\hline \multicolumn{2}{c|}{ 研究分担者 } & \multicolumn{1}{c}{ 所属施設 } \\
\hline 1 & 安井 信之 & 秋田脑血管研究セノター \\
\multicolumn{2}{c|}{ (故 伊藤太郎) } & 東北大学病院 \\
2 & 鈴木 二郎 & 美原記念病院 \\
3. & 水上 公宏 & 東京大学病院 \\
4 & 佐野 圭司 & 順天堂大学病院 \\
5 & 石井 昌三 & 信川大学病院 \\
6 & 杉田虔一郎 & 名古屋大学病院 \\
7 & 景山 直樹 & 京都大学病院 \\
8 & 半田 肇 & 国立循環器病セノター \\
9 & 菊他 晴彦 & 北野病院 \\
10 & 端 & 和夫 \\
11 & 西本 詮 & 岡山大学病院 \\
12 & 北村 勝俊 & 九川大学病院 \\
\hline
\end{tabular}

究者か参加し, 関連施設を含めて 27 の施設と 42 名の術 者か指定された（表 1). わか国の総症例数は1,131， らち手術例数は1,047（92 6\%）となり, 全世界症例の ほぼ $1 / 3$ 占めた。

この共同研究て対象とした症例は，のう状動脈虜第 1 回破裂によるくも膜下出血発作てあり, 患者は 18 歳 以上て, くも膜下出血てあることか, 病歷並ひに腰推 穿刺, CT 又は手術のいずれかにより確認されて打り, 又, 動脈虜そのものか, 動脈撮影か剖検て確かめられ たものて, 当該施設に, 出血発作当日を 0 日として 3 日以内に入院し，5 日以内にCTを行うこととされた。 手術の適応，時期については，一切指定術者の採択に 
よるものとされたが, 転帰に関しては, 術後 6 カ月の 時点で, 手術に関与しなかった第 3 者, 多くは神経内 科医が指定されて, 評価した。この共同研究の全体の

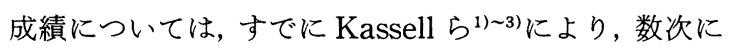
わたり報告されているが，それに大きく関与した日本 脳神経外科医の成績については報告されていない。わ が国の 12 研究者間の連絡, とりまとめ等には北村が当 たったので, Kassell, Torner の協力, わが国の分担研 究者の了解のもとに, その成績の一端を報告する.

\section{II. 成 績}

1. 対象の背景。（）内は全世界の症例についての 数値.

対象となった $1,131(3,521$ 例) のうち，女は58.6 (61.1)\%, 平均年齢は $54.2(50.4)$ 歳, 血圧は $153 / 90$ $(150 / 88) \mathrm{mmHg}$, 意識状態が清明又は傾眠程度のもの が70.0(81.1)\%で, わが国症例でわずかに年齢が高く, それだけに血圧もやや高いが，意識状態の比較的よい ものの占める割合はやや少ない，発作当日入院例の比 率は50.8(48.9)\%, 孤在性動脈瘤は $81.5(81.3) \%$ と ほとんど変らないが, 小動脈瘤88.5 (78.0)\%, 大動脈 瘤11.1（20.0)\%，巨大動脈瘤0.4（2.0)\%とわが国で は小さい動脈瘤がやや多い. 発生部位（表 2) は医と んど同じである。

\section{2. 手術時期 (表 3)}

入院時に計画した手術時期 (planned surgery interval）と実際に手術した時期 (actual surgery interval) とをみると, 当初計画では 3 日以内の手術がわが国で は $75.2 \%$, 全世界症例では $45.3 \%$, 実際の手術時期は
表 2 動脈瘤の発生部位

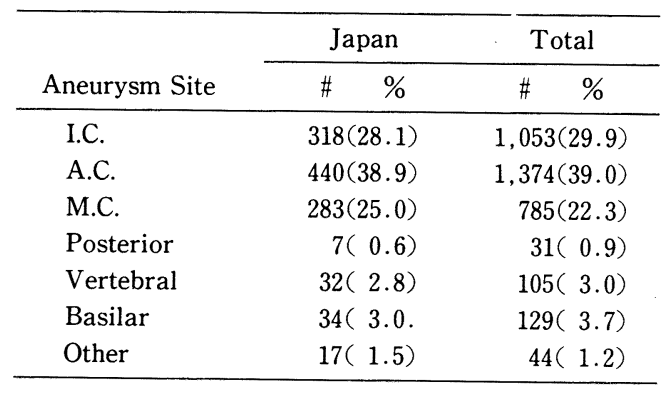

表 3 手術時期

\begin{tabular}{|c|c|c|c|c|c|}
\hline \multicolumn{3}{|c|}{ Planned Surgery Interval } & \multicolumn{3}{|c|}{ Actual Surgery Interval } \\
\hline & Japan & Total & & Japan & Total \\
\hline $0-3$ & $75.2 \%$ & $45.3 \%$ & $0-3$ & $71.1 \%$ & $42.0 \%$ \\
\hline $4-6$ & 4.7 & 10.6 & $4-6$ & 5.9 & 10.0 \\
\hline $7-10$ & 1.6 & 17.7 & $7-10$ & 2.3 & 10.5 \\
\hline $11-14$ & 4.8 & 12.3 & $11-14$ & 2.4 & 7.6 \\
\hline $15+$ & 6.4 & 7.0 & $15+$ & 7.0 & 12.9 \\
\hline No Surgery & 7.4 & 7.1 & No Surgery & 11.3 & 17.0 \\
\hline Total & 100.0 & 100.0 & Total & 100.0 & 100.0 \\
\hline
\end{tabular}

3 日以内の手術が, わが国では $71.1 \%$, 全世界症例で は $42.0 \%$ となっており，いずれについても，明らかに わが国では早期手術が指向され，実行されているのが らかがわれる. 当初手術適応なしとした率は, わが国 $7.4 \%$ ，全世界症例 $7.1 \%$ とほぼ同じであるが，実際に 手術されなかった割合は,わが国 $11.3 \%$, 全世界 $17.0 \%$ と, 全世界症例群で高い。このことは, 待機中に手術 適応から脱落していくものがかなりあることを物語る

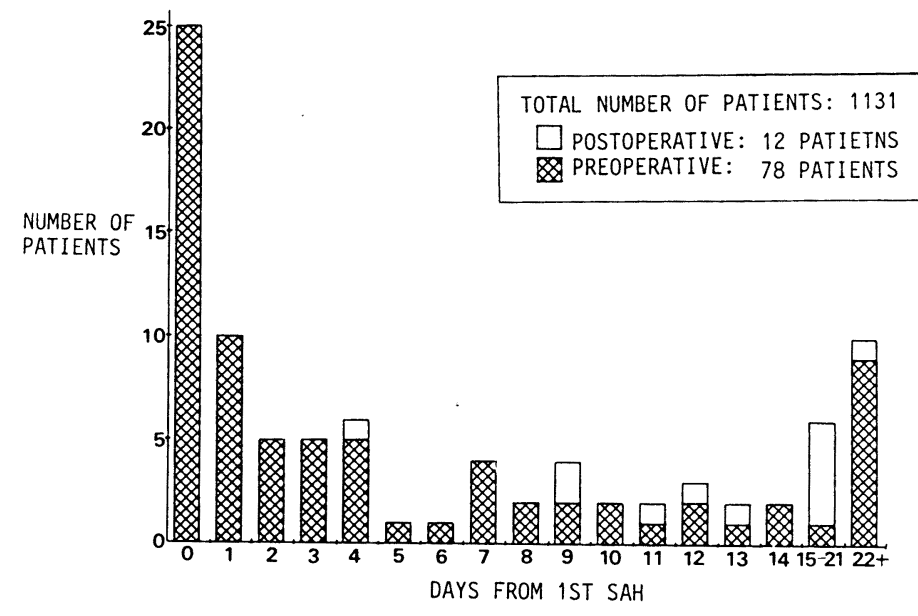

図 1 再出血の時期 


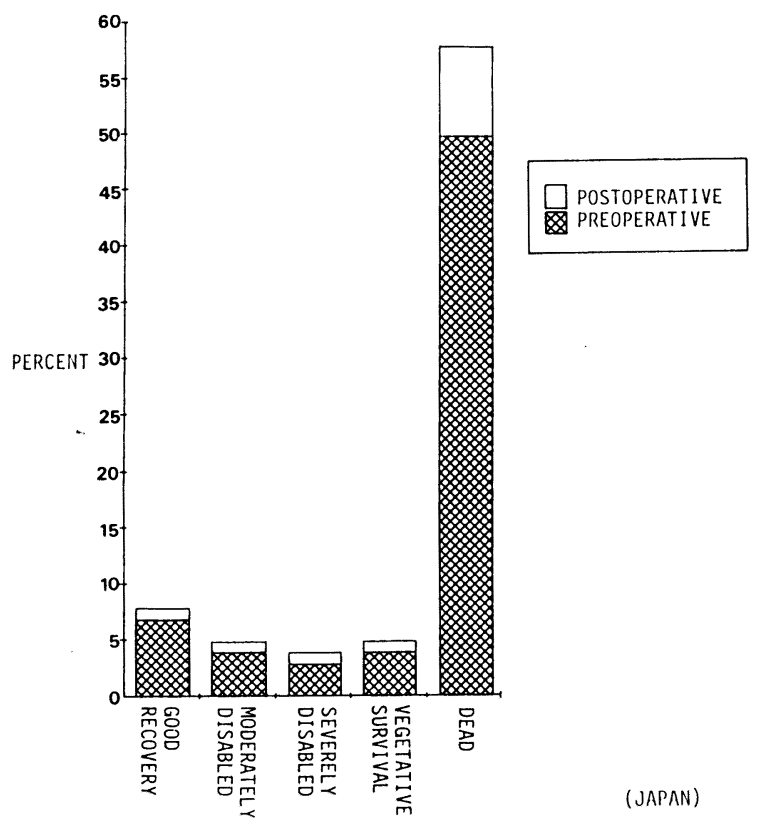

図 2 再出血症例の転㷌

ものと思われる. 手術時期決定における予後因子とし ては, 意識状態が比較的よく, 運動反応, 全身状態の よいもの, 中大脳動脈瘤のように比較的手術が容易で あろらと予測されるもの.CT では, mass effect が強 いか又は脳内血腫がある場合に早期手術が計画され，

脳底・椎骨動脈の動脈瘤では, 相当数のものが発症後 15日以降に計画されている。実際の手術はその後の状 態に応じて，計画より早く行い，あるいは逆に延期さ らには中止を余儀なくされるなど，上述のとおり変更 されている.

\section{3. 再出血}

再出血の時期は, 従来初回発作後 7 日目頃に多いと 考学られていたが5), 今回の全世界症例の検討では, 初 回破裂当日に再破裂を起こすものが最も多いことが明 らかにされている2).わが国の症例でも，第0日目の再 出血が最も多い(図 1). その後の再出血が少ないのは, 全症例の $70 \%$ 以上が 3 日以内に手術されているためと

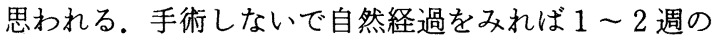
間, かなり高率の再出血が続くものと推測される 出血症例の転帰は図 2 のと拈りで, 死亡率が非常に高 い.もともと動脈瘤の手術は再出血防止にあることが, これからの数值から十分理解されよう。

\section{4. 血管攀縮}

再出血と並んで重大な問題は，〈も膜下出血後に起
こる、いわゆる晚発性血管攣縮である，わが国では， 動脈瘤破裂後早期に血管撮影が行われ，早期に手術さ れることが多いので，術前血管撮影では，93.4\%に血

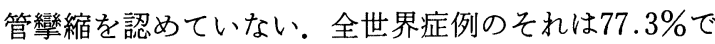

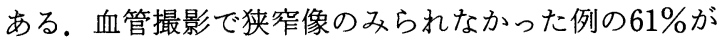
よい回復を示し， $21 \%$ 多亡，明らかに血管狭窄を示

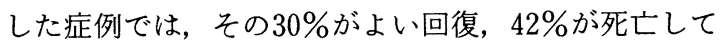
いる. 動脈狭窄の所見は, 手術時期の決定, 予後の判 定上重要であり, 術前のみでなく, むしろ術後の重大 課題として，今後一層検討すべき問題である.

\section{5. 術前の CT}

CT 所見と転㷌との関係をみると, CT 所見が正常の 症例の $85 \%$ はい転帰を取っており，逆に， mass effect のあるもの, 脳室内出血, 脳内出血を伴うもの は，いずれも $40 \%$ 以上の死亡率を示している。 くも膜 下腔の血液は，びまん性で厚い層を呈するものに死亡 率が高い.

\section{6. 術前の合併症}

術前合併症をみると，術前再出血は，わが国では $6.8 \%$, 全世界では $9.5 \%$, 局所脳虚血症状は, わが国 では $5.0 \%$ ，全世界では $11.7 \%$ と，わが国の場合がかな り少ない，早期手術であればあるほど術前合併症が少 ないのは当然であろう.動脈撮影に伴ら合併症は $1.1 \%$ にみられているが，これも全世界症例より少ない，水 頭症が $9.2 \%$ ，全世界の $2.2 \%$ り多いが，理由は不 明である。

\section{7. 術中の問題点}

脳神経外科医は，以上のような諸条件を勘案した上 で手術を行らことになるのであるが，その際どのよう な事態に遭遇するかを，手術時期に分けて検討してみ た.

急性期の手術でまず問題になるのは，脳が腫れてい て動脈瘤に達するのが困難ではないかということであ る。事実, 早期にはその傾向が強く, 破裂当日とその 翌日の手術では, 半数近くの症例で, 術者は tight brainの印象を持っている。脳を無理に圧排して脳挫 傷をきたすことは，早期には1.4\%程度起こっている が，15日以後の晚期手術にもあり，注とんどの症例で, tight brain であると感じ乍らも，認むべき脳挫傷をき たすこととなく手術が行われている。ささらに動脈瘤の 剥離の困難さ, あるいは術中の動脈瘤からの血液漏出, さらに動脈瘤破裂が危惧されるが，いずれについても， 早期が不利であり，晚期では安全であるといら結果は 得られていない。動脈瘤からの血液漏出, 動脈瘤破裂 
は, どの時期の手術でも10 20\%程度に起こっており， 動脈瘤剝離の困難さは，0-1 日では $38 \% ， 5-9$ 日 では $67 \%$ と，むしろ時期が少しおくれた時の方にやや 大きい印象さえある。術中の問題点, 手術の態様を, 全世界の場合と対比してみたのが表 4 である. tight brain の印象がわが国でやや多いのは，早期例が多い ためかとも思われる。しかしながら, そのために, 脳 の切除を要したり, 脳挫傷を招いたり,さらには術中 動脈瘤の破裂をきたしたりするなど，不利な状況に陷 ることは, わが国の症例でむしろ少なく, 全体として 手際よく手術が行われているといえよう。クリッピン グを行った率はほとんど変らない。

\section{8. 転帰}

実際の手術時期別に 6 カ月後の評価でよい回復を示 したものを図示したのが図 3 である. 図の左半は, 生 の数值を\%で表したもの, 右半は, 各時期群での risk

表 4 術中の問題点と手術の態様

\begin{tabular}{lcc}
\hline & Japan & Total \\
\hline Exposure Tight & $36.7 \%$ & $33.6 \%$ \\
Major Resection & 1.5 & 3.4 \\
Brain Contusion & 1.2 & 1.5 \\
Brain Laceration & 0.1 & 0.8 \\
Dissection Difficult & 41.8 & 45.8 \\
Leak & 3.8 & 9.5 \\
Rupture & 11.1 & 21.9 \\
Occlusion of Feeding & 2.2 & 3.1 \\
or Perfor. Arteries & 1.3 & 1.4 \\
Intracerebral Hemorrh. & 0.8 & 1.1 \\
Hemorrh. Hypotension & 92.6 & 93.5 \\
Clipping & & \\
\hline
\end{tabular}

factorの差について, proportional hazard model よる補正を加えたものである，早期と晚期で，著しい 差はないが，補正值でみると，7-10日の群にやや低 い谷がみられる，意識状態のよいものと悪いものとに 分けてみても，いずれについても，早期手術，晚期手 術の間に著しい差はみられない。逆に 6 力月以内に死 亡したものについてみると(図 4), 明らかに 6 日以内 の手術群で死亡率が高い。 $0-3$ 日手術群で, 意識清 明なものの死亡率は $5 \%$, stupor, coma 群の死亡率は 35\%である。わが国の症例では晚期手術例が少なく, 死亡率について，さらに意識障害別に論じることはこ の段階では差控えたい.1974-1975年の 2 年間のわが 国脳神経外科の手術経験例 2,908 例について集計分析 した西本ら ${ }^{4)}$ の報告では，18\%が 7 日以内に手術を受 け，その死亡率は $39 \%$ であった。手術死亡率の高さか ら，早期手術に対する強い批判もあったが，今回の共 同研究の集計では 3 日以内の手術が，わが国の症例で は $71 \%$, 全世界の症例でも $42 \% を$ 占め，全体として急 速に早期手術例が増加を示している。手術死亡率も今 回のわが国症例では，3 日以内の手術例で15\%であり， 数年前からみると激減してきている。このことは, 何 よりも治療法, 手術手技の格段の向上によるものと思 われる。

\section{9. 不幸な転帰の原因}

くも膜下出血そのものの直接障害と動脈攣縮, とが, 死因としても機能障害の原因としても $25-40 \%$ を占め ている，再出血は機能障害よりも死亡の原因となりや すい. 外科手術は機能障害の $11 \%$, 死亡の $4 \%$ で原因 となっている.手術の良否は与えられた状況でなく,

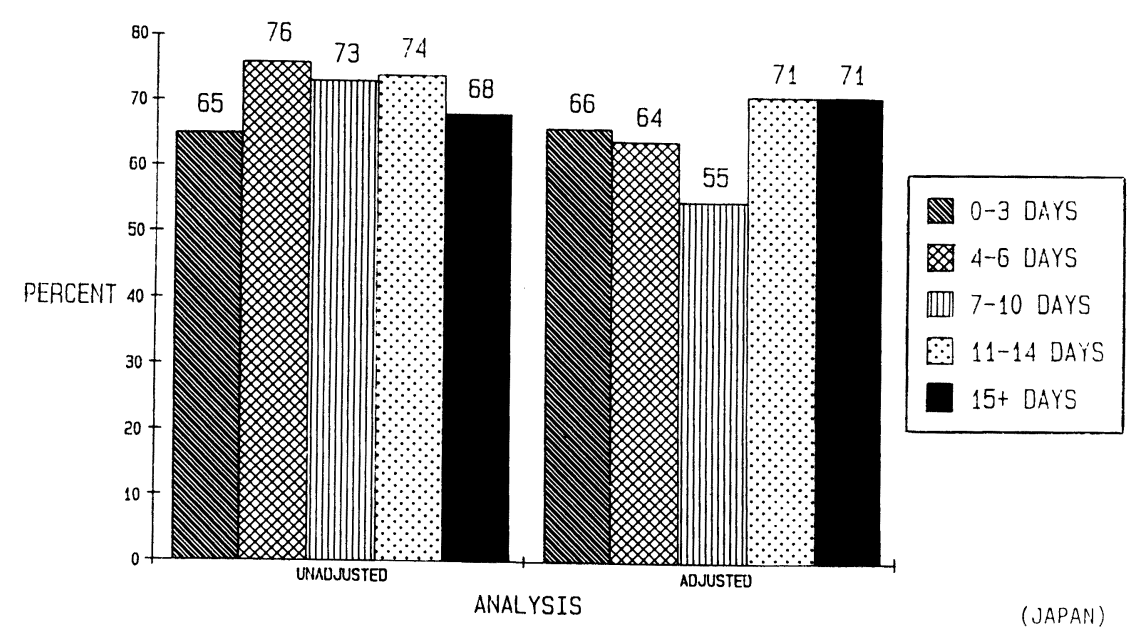

図 3 よい回復症例の手術時期別頻度（左は生の数值, 右は補正値) 


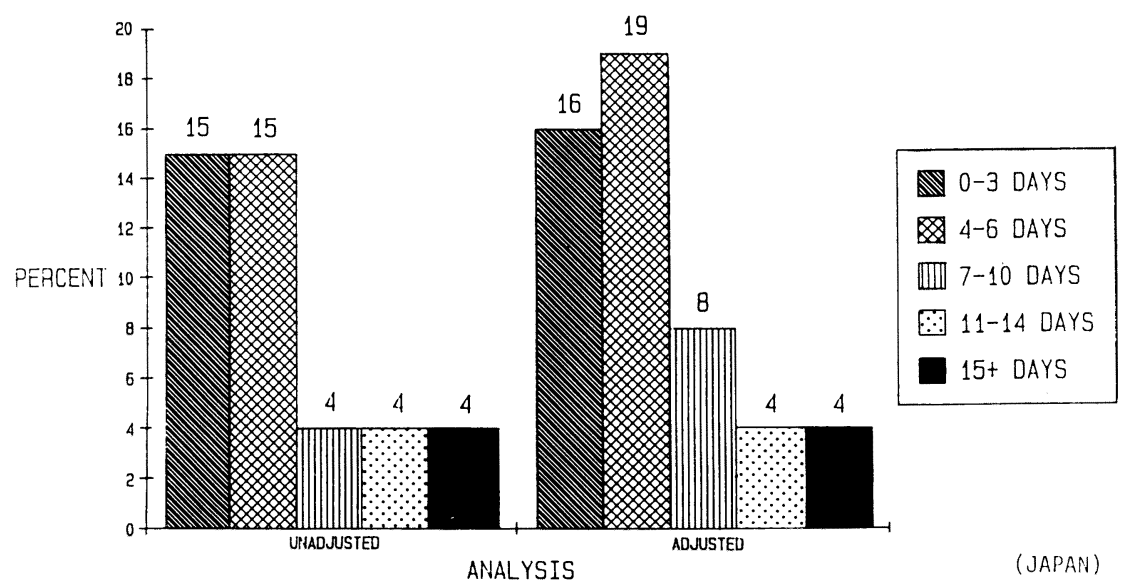

図46 月死亡症例の手術時期別頻度（左は生の数値, 右は補正值)

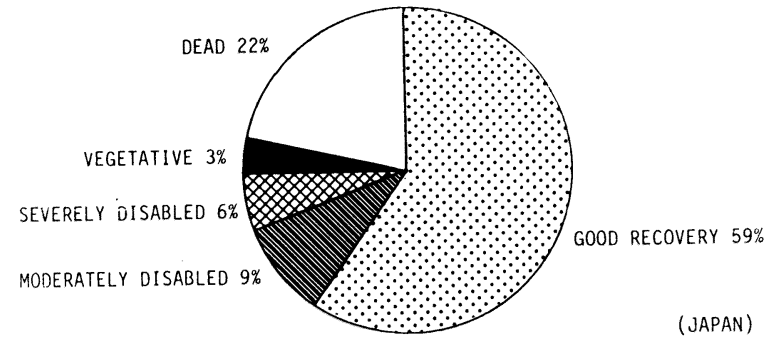

図 5 わが国1,131例の転帰

術者の努力によって向上し得るものであるので，外科 医として不断の努力が要求される。これらの原因を手 術時期との関連でみると, 直接障害と動脈攣縮とが早 期手術群でやや多い。動脈攣縮が障害又は死亡の原因 と考えられる率は，0-3 日手術群で最も高く，つい で11日以降の手術群に多く，4-10日の手術群で最も 少ない。早期に手術すれば，動脈攣縮が防止できると はいえないようであり、又, 動脈攀縮の発生しやすい 4 -10日の手術で, 特に動脈攣縮が転帰を悪くすると いらことにもならないよらである。良好な回復を示し た症例のらちで，7-10日手術群に低い谷がみられた こととともに，将来一層検討すべて問題であろう.

\section{0. 成績のまとめ}

わが国の全症例の結果をまとめると, 図 5 のと打り

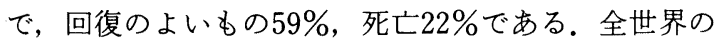
症例では, 回復のよいもの $58 \%$, 死亡 $26 \%$ で, わが国 の成績は, わずかながら全体の成績よりよい。わが国 の症例を手術計画 0-3 日群と 7-14日群とに分けて みると，よい回復はそれぞれ $65 \%, 58 \%$ ，死亡は $16 \%$ ，
$21 \%$ といずれについてみても, 早期群の成績が少しょ い. 早期手術計画群と晚期手術計画群の間には, 様々 な予後因子が含まれており，この成績から直ちに結論 し難いが，少なくとも早期手術計画が全体として不当 であったこと示唆する点はないように思われる. 又全 体として早期手術症例の多いわが国の成績も, 全世界 の成績に比べて優るとも劣るものでは決してない.

\section{III. むすび}

1） $1981-1984$ 年の国際共同研究のうちの約 $1 / 3$ を占 めた, わが国脳神経外科医の症例1,131例の成績を, 全 世界のそれと対比しながら紹介した。

2）わが国の症例の背景は, 全世界のそれとほとんど 同様であった。

3）わが国では, 早期手術症例が多かったが, 術中の 合併症は，早期手術で特に多いとはいえず，又，わが 国の症例では, 全世界の症例に比べて, 術中の合併症 はむしろ少なかった。

4）よい回復症例の頻度は, 早期手術群之晚期手術群 の間にあまり差はなく，むしろ $7-10$ 日手術群に低い 谷間がみられた。

5）死亡率は, 早期群に高く，11日以後の手術群で最 も死亡率が低かった。

6）全体の成績では, わが国の成績が全世界の成績よ りわずかによかった。

7）破裂脳動脈瘤の手術時期は, 個々の症例について 慎重に考慮すべきであるが，全体としては，早期手術 を指向しつつ, 手術手技, 術前・術後の治療・管理の 向上に努むべきであろう。 
わが国の分担研究者からは終始絶大な協力を頂いた. 又, 本論文中の集計数值は, Dr. Kassell, Dr. Torner から全面 的な提供を受けた。ここに記して深甚の謝意を表したい。

\section{文献}

1) Kassell NF, Torner JC: The International cooperative study on timing of aneurysm surgery. Acta Neurochir 63: 119-123, 1982

2) Kassell NF, Torner JC: Aneurysmal rebleeding : a preliminary report from the cooperative aneurysm study. Neurosurgery 13: 479-481, 1983

3) Kassell NF, Torner JC: The International cooperative study on timing of aneurysm surgery - an update. Stroke 15: 566-570, 1984

4) Nishimoto $A$, Ueta $K$, Onabe $H$, et al: Nationwide co-operative study of intracranial aneurysm surgery in Japan. Stroke 16: 48-52, 1985

5) Locksley HB: Report on the cooperative study of intracranial aneurysms and subarachnoid hemorrhage. Section V, Part II. Natural history of subarachnoid hemorrhage, intracranial aneurysms and arteriovenous malformations. Based on 6368 cases in the cooperative study. J Neurosurg 25 : 321-368, 1966 